DOI https://doi.org/10.51647/kelm.2021.1.1.9

NAUKA ROZUMIENIA ZE SEUCHU W INSTYTUCJACH SZKOLNICTWA WYŻSZEGO

\author{
Natalia Tarasiuk \\ wykładowca Katedry Języka Angielskiego Kierunku Humanistycznego nr 3 \\ Narodowego Uniwersytetu Technicznego Ukrainy \\ „Kijowski Instytut Politechniczny imienia Igora Sikorskiego" (Kijów, Ukraina) \\ ORCID ID: 0000-0002-6683-3588 \\ E-mail: tarasiuk.nataliia@lll.kpi.ua
}

\begin{abstract}
Adnotacja: W artykule omówiono proces nauki rozumienia ze słuchu na zajęciach z języka obcego w instytucjach szkolnictwa wyższego. Opisano cechy etapów nauki rozumienia ze słuchu na różnych kursach szkoleniowych, przedstawiono przykładowe zadania. W pracy podkreślono, że podstawą procesu rozumienia ze słuchu jest tekst audio. Opisano podstawowe kryteria doboru tekstów audio do kształcenia audiowizualnego w instytucjach szkolnictwa wyższego. Szczególną uwagę zwrócono na zalety i wady wykorzystania materiału wideo w nauce rozumienia ze słuchu. Należy zauważyć, że wykorzystanie zasobów internetowych do nauki rozumienia ze słuchu daje możliwość uczynienia uczenia się bardziej efektywnym, znacznie zwiększa motywację uczniów. Scharakteryzowano główne trudności, jakie mają studenci szkół wyższych podczas słuchania tekstów na temat specjalizacji. Zaleca się uwzględnienie wyróżnionych trudności podczas opracowywania ćwiczeń do nauki rozumienia ze słuchu uczniów szkół wyższych.

Słowa kluczowe: nauka rozumienia ze słuchu, rodzaje rozumienia ze słuchu, tekst audio, trudności z rozumieniem ze słuchu, materiały wideo, zasoby internetowe.
\end{abstract}

\title{
TEACHING LISTENING COMPREHENSION AT HIGHER EDUCATIONAL INSTITUTIONS
}

\author{
Natalia Tarasiuk \\ Lecturer at the Department of the English Language of Humanities Orientation № 3 \\ National Technical University of Ukraine "Igor Sikorsky Kyiv Polytechnic Institute" (Kyiv, Ukraine) \\ ORCID ID: 0000-0002-6683-3588 \\ e-mail: tarasiuk.nataliia@lll.kpi.ua
}

\begin{abstract}
The article deals with teaching listening comprehension at higher educational institutions. The author describes the stages of teaching listening and provides different tasks for listening activities. The main criteria for selecting listening materials for teaching listening comprehension at higher educations are described. The paper highlights the importance of listening material in teaching listening. Particular attention is paid to the advantages and disadvantages of using video materials in teaching listening skills. The author emphasizes that using internet resources for teaching listening skills makes lessons more efficient and increases students' motivation. Typical difficulties of listening comprehension of professional-oriented text are characterized. The author recommends taking into consideration these difficulties while developing exercises for teaching listening professional-oriented texts at higher educational institutions.

Key words: teaching listening comprehension, types of listening, audio material, difficulties of listening comprehension, video materials, internet resources.
\end{abstract}

\section{НАВЧАННЯ АУДІЮВАННЯ В ЗАКЛАДАХ ВИЩОЇ ОСВІТИ}

\author{
Наталія Тарасюк \\ викладач кафедри англійської мови гуманітарного спрямування № 3 \\ Національного технічного університету Украӥни «Київський політехнічний інститут \\ імені Ігоря Сікорського» (Київ, Україна) \\ ORCID ID: 0000-0002-6683-3588 \\ e-mail:tarasiuk.nataliia@lll.kpi.ua
}

Анотація. У статті розглядається процес навчання аудіювання на заняттях іноземної мови в закладах вищої освіти. Описано особливості етапів навчання аудіювання на різних курсах навчання, наведено зразки завдань. У роботі підкреслено, що основою процесу аудіювання є аудіотекст. Описано основні критерії відбору аудіотекстів для навчання аудіювання в закладах вищої освіти. Особлива увага приділена перевагам і недолікам використання відеоматеріалів у навчанні аудіювання. Наголошено, що використання інтернет-ресурсів для навчання аудіювання дає можливість зробити навчання більш ефективним, значно підвищує мотивацію студентів. Охарактеризовано основні труднощі, які виникають у студентів вищих закладів освіти під час аудіювання текстів за спеціальністю. Рекомендовано враховувати виділені труднощі під час розроблення вправ для навчання аудіювання студентів закладів вищої освіти.

Ключові слова: навчання аудіювання, види аудіювання, аудіотекст, труднощі аудіювання, відеоматеріали, інтернет-ресурси. 
Вступ. Володіння іноземними мовами для сучасного фахівця є надзвичайно важливим. Особливо важливо це для фахівця технічних спеціальностей. Сучасний фахівець повинен мати комунікативні навички з різних видів мовленнєвої діяльності: аудіювання, говоріння, читання, письма. Опанування навичок аудіювання дає можливість сприймати і розуміти іноземну мову на слух.

Навчання аудіювання розглядали у свої роботах багато вітчизняних науковців, зокрема: С.В. Гапонова, О.Г. Квасова, С.Ю. Ніколаєва, О.П. Тарнопольський. І.В Коваль, З.П. Овчаренко дослідили причини виникнення труднощів в навчанні аудіювання, способи їх подолання. У роботах О.В. Кміть описуються критерії підбору текстів для аудіювання. Серед закордонних дослідників варто згадати таких: J. Field, J. Flowerdew, C. Goh, T. Hedge, L. Miller.

Основна частина. Мета статті - розглянути особливості навчання аудіювання на заняттях з іноземної мови в закладах вищої освіти.

Під аудіюванням розуміють процес рецептивної мовленнєвої діяльності, яка забезпечує розуміння того, що сприймається на слух. Аудіювання є комплексною розумовою діяльністю (Стогній, Никанорова, 2018: 183). На формування навичок аудіювання істотно впливають загальні інтелектуальні здібності людини, знання рідної мови, рівень володіння іноземної мовою, мотивація.

У методичній літературі виділяють такі види аудіювання (Тарнопольський, 2006: 148):

- розпізнання звуків - основною метою $є$ розпізнання і розуміння окремих звуків;

- розуміння основного змісту - виділення основної інформації, не звертаючи увагу на деталі;

- аудіювання 3 повним розумінням тексту - розпізнання і розуміння основної інформації і деталей;

- аудіювання з вибірковим розумінням тексту - спрямоване на виділення тільки окремої інформації з усього тексту.

У закладах вищої освіти (далі - ЗВО) навчання аудіювання відбувається в контексті комплексної підготовки фахівців окремої галузі. Важливо навчити студента розуміти на слух лекції викладачів за спеціальністю, слухати наукові доповіді, презентації, виділяти основну інформацію. Розглянемо процес навчання аудіювання. У методиці виділяють декілька етапів навчання аудіювання (Nation, Newton, 2009: 25):

- підготовчий етап;

- етап прослуховування;

- завершальний етап.

На підготовчому етапі викладач ознайомлює студентів із темою, підготовлює до сприйняття тексту. На цьому етапі викладач пропонує студентам вправи, які допомагають подолати фонетичні, лексичні та граматичні труднощі аудіювання.

На етапі прослуховування викладач навчає студентів виділяти основну інформацію 3 аудіотексту, концентрувати увагу на головному, відкинути зайві деталі.

На завершальному етапі перевіряється розуміння прослуханого матеріалу за допомогою різноманітних вправ, тестів множинного вибору, запитань.

На молодших курсах метою навчання аудіювання є розпізнання і розуміння інформації, а також уміння виокремлювати й аналізувати основну інформацію. Для навчання аудіювання із цією метою використовуються вправи, спрямовані на виділення окремої інформації, аналізу і порівняння. Наведемо приклади завдань:

Put the sentences in the correct group.

Listen to the text and divide ideas into 4 categories.

На старших курсах рекомендується вправи для навчання аудіювання поєднувати із вправами на розвиток навичок говоріння. Наведемо приклади завдань:

Listen to the conversation and speak about challenges of different professions. How do you overcome them?

Listen to four different people talking about their job. Speak about pros and contras of this project.

Listen to the text and divide ideas into 4 categories.

Основою для аудіювання є аудіотекст. Аудіотексти відрізняються своєю структурою і композицією, темпом звучання, а також інтонаційним оформленням. Серед основних вимог до аудіотекстів визначають (Field, 2008: 25):

- відповідність віковим особливостям студенів;

- відповідність ступеню сформованості мовленнєвих умінь у студентів / рівню володіння іноземною мовою;

- інформативність і цікавість матеріалів;

- логічність і чітка структура матеріалів;

- автентичність матеріалів;

- матеріали мають представляти різні форми мовлення;

- відповідність матеріалів тематиці заняття курсу.

На нашу думку, під час відбору текстів для навчання аудіювання у ЗВО викладач має насамперед звернути увагу на те, чи тексти відповідають професійній тематиці курсу та рівню володіння іноземною мовою, чи містять цікавий інформативний матеріал. Використанням автентичного аудіоматеріалу викладач дає можливість студентам почути правильну вимову технічних термінів за спеціальністю, зануритися в мовне середовище, що значно мотивує студентів.

Доречним $є$ використання відеофільмів, коротких відеороликів, анонсів програм за спеціальністю, оскільки зорове сприйняття, емоції персонажів, невербальна комунікація сприяють 
розумінню текстів. Низка авторів виділяють переваги використання відеоматеріалів для навчання аудіювання

(Flowerdew, Miller, 2005: 67), а саме:

- автентичність матеріалів;

- створення відповідного мовного середовища;

- підвищення мотивації студентів;

- відображення реальної ситуації використання мови;

- ефективне засвоєння матеріалу.

Крім переваг. варто також звернути увагу на труднощі, які можуть виникнути під час навчання аудіювання за допомогою відеоматеріалів. Під час перегляду відеофільмів студенти часто переключають увагу на картинку і забувають про аудіювання. Тому важливо чітко окреслити завдання перед початком перегляду.

Актуальним $€$ використання інтернет-ресурсів і комп'ютерних технологій для навчання аудіювання у ЗВО. Використання інтернет-ресурсів дає можливість зробити навчання аудіювання цікавим і ефективним. Викладачі можуть зараз користуватися великою кількістю матеріалів, наявних в інтернеті (YouTube, British Council, BBC, EslLab, TEDTalks тощо). За допомогою згаданих ресурсів викладачі мають можливість обирати матеріали за спеціальністю і рівнем складності, додавати субтитри.

У плануванні заняття важливо брати до уваги низку труднощів, які виникають у студентів під час аудіювання. Автори виділяють такі категорії труднощів у навчанні аудіювання (Проценко, 2015: 187):

- мовні, це труднощі які зумовлені граматичними, лексичними і фонетичними особливостями матеріалу;

- індивідуальні особливості сприйняття;

- труднощі, спричинені умовами пред'явлення матеріалу.

Щоб підвищити ефективність навчання аудіювання професійно орієнтованих текстів, на підготовчому етапі доцільно опрацювати терміни і скорочення, які трапляються в тексті. Викладач може запропонувати студентам опрацювати вимову нової лексики в парах, потім закріпити в невеличких висловлюваннях і діалогах. У разі необхідності можна використовувати текст аудіоматеріалу під час прослуховування як опору. Дуже важливо створити атмосферу успіху на занятті, стимулювати студентів.

Висновки. У цьому дослідженні ми розглянути особливості навчання аудіювання на заняттях іноземної мови в закладах вищої освіти. Навчання аудіювання у ЗВО проходить в декілька етапів, які мають свою структуру й особливості проведення. Перевагами використання відеоматеріалів та інтернет-ресурсів для навчання аудіювання у ЗВО є створення відповідного мовного автентичного середовища, ефективне засвоєння матеріалу, підвищення мотивації студентів. На нашу думку, обов'язково необхідно брати до уваги фонетичні, граматичні та лексичні труднощі, з якими стикаються студенти під час аудіювання професійно орієнтованого тексту. У перспективі - розроблення комплексу вправ для навчання аудіювання студентів молодших курсів технічних закладів вищої освіти.

\section{Список використаних джерел:}

1. Field J. Listening in the language classroom. Cambridge : Cambridge University Press, 2008.

2. Flowerdew J., Miller L. Second language listening: Theory and practice. Cambridge : Cambridge University Press, 2005.

3. Nation P., Newton J. Teaching ESL/EFL listening and speaking. London : Routledge, 2009.

4. Квасова О.Г. Основи тестування іншомовних навичок і вмінь : навчальний посібник. Київ : Ленвіт, 2009.119 с.

5. Проценко Н.В. Основні труднощі аудіювання. Наукові праці Кам'янець-Подільського національного університету імені Івана Огієнка. Серія «Філологічні науки». 2012. Вип. 29 (1). С. 87-89.

6. Стогній І.В., Никонорова Л.І. Формування навичок аудіювання у студентів вищих навчальних закладів. Науковий вісник Національної академії статистики, обліку та аудиту. Серія «Суспільство. Світогляд. Наука. Культура». 2013. № 1. C. 87.

\section{References:}

1. Field, J. (2008). Listening in the language classroom. Cambridge: Cambridge University Press.

2. Flowerdew, J., \& Miller, L. (2005). Second language listening: Theory and practice. Cambridge: Cambridge University Press.

3. Nation, P., \& Newton, J. (2009). Teaching ESL/EFL listening and speaking. London: Routledge.

4. Kvasova O.H. (2009). Osnovy testuvannia inshomovnykh navychok i vmin. [The Basics of testing foreign language skills and abilities] Kyiv; Lenvit.

5. Protsenko N.V. (2012). Osnovni trudnoshchi audiiuvannia. [The main difficulties of listening]. Naukovi pratsi KamianetsPodolskoho natsionalnoho universytetu imeni Ivana Ohiienka.

6. Stohnii I.V., Nykonorova L. I. (2018). Formuvannia navychok audiiuvannia u studentiv vyshchykh navchalnykh zakladiv. [Formation of listening skills in students of higher educational institutions]. Naukovyi visnyk Mizhnarodnoho humanitarnoho universytetu. 